\title{
The Historical Evolution and Practical Experience of the Central Government's Strategy of Governing Hong Kong
}

\author{
Qingxiang Feng ${ }^{1}$ \\ ${ }^{1}$ The Center for Studies of Hong Kong Macao and Pearl River Delta, Sun Yat-sen University, Guangzhou 510275, China \\ Correspondence: Qingxiang Feng, The Center for Studies of Hong Kong Macao and Pearl River Delta, Sun Yat-sen \\ University, Guangzhou 510275, China.
}

Received: October 5, 2020

doi:10.11114/ijsss.v8i6.5062
Accepted: October 26, $2020 \quad$ Available online: October 28, 2020

URL: https://doi.org/10.11114/ijsss.v8i6.5062

\begin{abstract}
The central government's strategy of governing Hong Kong is the policy and strategy used by the central government to govern Hong Kong, which as a whole reflects the central government's institutional arrangements, power and responsibility relations, policy trends and governance goals for Hong Kong. As a dynamic historical category, the central government's strategy of governing Hong Kong has gone through the arduous exploration of several generations of communists and accumulated rich practical experience, providing a direction guide for the development of "One country, Two systems". Since the founding of the People's Republic of China, Mao Zedong's strategy of "temporarily not intervening Hong Kong" has been embodied in the policy of "long-term planning and full utilization" of governing Hong Kong, which has important historical reference significance. Deng Xiaoping inherited and developed Mao Zedong's strategic thinking on the peaceful reunification of the country and put forward the scientific concept of "One country, Two systems", which was successfully applied in Hong Kong. Jiang Zemin and Hu Jintao further enriched and developed the policy of "One Country, Two Systems", opening a new chapter in Hong Kong's development. Xi Jinping did not forget the original intention of "One Country, Two Systems" and led the central government's strategy of governing Hong Kong into a new era.
\end{abstract}

Keywords: One country, Two systems, the governance of Hong Kong, historical evolution, practical experience

\section{Introduction}

The report of the 19th National Congress of the Communist Party of China regards adherence to "One country, Two systems" and the promotion of the reunification of the motherland as one of the 14 basic strategies for socialism with Chinese characteristics in the new era, demonstrating the important status of the development of Hong Kong, Macao and Taiwan in the overall national development strategy. As a special administrative region directly under the central government, Hong Kong and Macao have been re-incorporated into the national governance system from the day of their return. Maintaining national sovereignty, security, and development interests, and maintaining the long-term prosperity and stability of Hong Kong and Macao society have always been a major issue for the central government to govern the country. In view of the complexity and typicality of the Hong Kong issue, how to manage Hong Kong well and implement the central government's overall governance power has attracted great attention from the central government and all sectors of Hong Kong society. Since Hong Kong has returned to the motherland for more than 20 years, reviewing, combing and summarizing the historical evolution process and practical experience of the central government's strategy of governing Hong Kong will be of great benefit for continuing to push forward the cause of "One country, Two systems" and upgrading the modernization of the national governance system and governance capacity.

\section{The Exploration and Evolution of the Central Government's Strategy of Governing Hong Kong}

Hong Kong has been an inseparable part of China since ancient times. However, the late Qing government was corrupt and incompetent, and western powers took advantage of it and illegally forcibly occupied Hong Kong as a "colony". Since then, Hong Kong has become a problem left over from Chinese history. With the founding of the People's Republic of China, the Communist Party of China has become the ruling party of China, and the historical mission of national reunification and the realistic task of Hong Kong governance naturally fall on the shoulders of the Communists. 


\subsection{Mao Zedong Explores the Way to Deal with the Hong Kong Issue: "Long-term Plan, Make Full Use of it."}

As one of the greatest statesmen, strategists and theorists in the 20th century, Mao Zedong is not only the main founder of the People's Republic of China, but also the earliest decision-maker of the Communist Party of China's strategy for Hong Kong. He thinks about the Hong Kong issue from both domestic and international perspectives, and runs the strategy of "temporarily not intervening Hong Kong" through the policy of "long-term planning and full utilization".

Judging from the domestic environment, domestic production factors such as commodities, capital, technology and management were in short supply in the early stage of socialist construction. Relying on endogenous resources alone was not enough to meet the people's growing material and cultural needs. Therefore, using exogenous resources became a necessary supplement to solve the contradiction between productivity and production relations. Hong Kong, as the only transit point among Europe, America and Southeast Asia in China at that time, not only provided a circulation channel for patriotic overseas Chinese to input capital, talents and other resources to the mainland, but also provided a convenient trade window for strategic materials such as petroleum and chemical industry needed for domestic production. Its domestic role and international strategic position were crucial in a specific historical period. In this regard, the central government pointed out through objective analysis that Hong Kong is a major trade route. If we control it now, it will be unfavorable to world trade and our trade relations with the world. We are not prepared to intervene it for the time being (Mao, 2013); Hong Kong can only exist and develop if it acts in full accordance with the capitalist system, which is beneficial to us (Zhou, 1984).

In view of the international environment, the western capitalist countries headed by the United States isolated, blocked and surrounded China from political, economic and military aspects, with the intention of stifling the new socialist China in the cradle of the Cold War. On the one hand, for the sake of its special economic interests in China, Britain does not stand on the same political front with the United States and other western countries; On the other hand, the British government lacks confidence in relying on its own strength to protect its dominant position in Hong Kong in the face of the overwhelming Chinese People's Liberation Army (Liu,1998). On the issue of Hong Kong's political future, it frequently releases the willingness and signals of dialogue and consultation to the Chinese government, and strives to retain its privileges in Hong Kong as much as possible. The British hope that Hong Kong will not be controlled by the Communist Party by emphasizing Hong Kong's important position in trade with China and expressing their willingness to discuss Hong Kong's political future with the Communist Party (Martin,2016). The Chinese government took advantage of the trend and exchanged temporary economic interests for long-term political interests, thus gaining public recognition of the ruling legitimacy status of the Communist Party of China by sovereign countries such as Britain and the international community.

Under such complicated historical background, if New China wants to solve the main contradictions in the primary stage of socialism and consolidate the new political power, it cannot repeat the Cold War thinking of western countries against China. We must proceed from the world situation, national conditions and regional conditions, and adhere to the strategy of combining the consistency of principles with the flexibility of countermeasures. In short, both stick to the bottom line and leave room. Specifically, the bottom line of the Chinese government is to firmly safeguard national sovereignty and territorial integrity, and never recognize the three unequal treaties imposed on China by Britain in the form of war of aggression in modern times. The leeway is to choose the right time to resolve the Hong Kong issue peacefully through negotiation, and to maintain the status quo of Hong Kong for the time being before it is resolved. These ideological strategies are the central government's basic stand, proposition and method in dealing with the Hong Kong issue, that is, the core essence of the policy of "long-term planning and full utilization".

Seeking truth from facts is the essence of Mao Zedong Thought. The first generation of collective leadership with Comrade Mao Zedong as the core respects history and bases itself on reality, and has accumulated rich experience in the process of exploring ways to solve the Hong Kong problem left over from history. Its strategy of "long-term planning and full utilization" is closely related to the concept of "One country, Two systems". It can be said that Mao Zedong, Zhou Enlai and other central decision-makers have made beneficial theoretical and practical explorations in the cause of the reunification of the motherland, providing important historical resources and reference experience for Deng Xiaoping to creatively put forward the great idea of "One country, Two systems".

\subsection{Deng Xiaoping Explores the Solution to the Hong Kong Issue: "Peaceful Reunification, One Country, Two Systems"}

Deng Xiaoping's scientific conception of "One country, Two systems" is the inheritance and development of Mao Zedong Thought's strategy of peaceful reunification of the country. The policy of "One country, Two systems" originated at the beginning of China's reform and opening up, and gradually formed in Ye Jianying's "Nine Policies" for Taiwan (Ye, 1981). "One country, Two systems" was originally designed for the peaceful reunification of Taiwan. However, it was first successfully applied to solve the more urgent Hong Kong issue due to the complexity, arduousness and protracted nature of the Taiwan issue. Deng Xiaoping is well versed in the cultural tradition of "great unity" of the Chinese nation, 
understands the situation of domestic reform and opening up and the trend of world peace and development, and puts forward the best solution to the Hong Kong problem from the historical inevitability and realistic possibility. It is the desire of the nation to realize national reunification. If it is not unified in a hundred years, it will be unified in a thousand years. In my opinion, the only way to solve this problem is to implement "One country, Two systems" (Deng, 1993).

First of all, "One country, Two systems" means that the practice of socialism in the Mainland and capitalism in Hong Kong is a synchronic social existence in the territory of the People's Republic of China. Looking at the institutional forms of various countries in the world, there has never been a precedent of "one country" coexisting with "two systems". Only the Chinese Communist Party and the Chinese government are so open-minded and courageous, and they show a high degree of theoretical and cultural self-confidence in the process of promoting socialism with Chinese characteristics. Secondly, on the basis of the resumption of exercise of sovereignty over Hong Kong, the state respects Hong Kong's actual conditions, maximizes Hong Kong's characteristics and advantages, and maintains long-term prosperity and stability of Hong Kong. This flexibility of the system is a manifestation of the vitality of "One country, Two systems". Thirdly, it bears two different social systems in a unitary state structure, which puts forward higher requirements of modern state governance for the integration of central and local power relations. In other words, there are two different economic foundations and superstructures in a national system. How can they be integrated and coexisted? It is a very challenging attempt to social practice itself.

No matter from which perspective, "One country, Two systems" is an institutional innovation containing a new world outlook and methodology, which undoubtedly requires great boldness and courage of the Chinese Communists. Such a strategic choice is neither a temporary impulse nor a gimmick. It is based on reality and takes full account of Hong Kong's history and current situation (Deng, 1993). It is the vivid manifestation of re-establishing the ideological line of seeking truth from facts at the Third Plenary Session of the Eleventh Central Committee of the Communist Party of China. The smooth advancement of China's reform and opening-up has provided a realistic foundation for a country to accommodate two different political systems. Without a solid foundation for development and a growing comprehensive national strength, the practice of "One country, Two systems" in Hong Kong may become empty talk.

As an important part of Deng Xiaoping Theory, "One country, Two systems" embodies the collective wisdom of the Chinese Communists and provides direction guidance and practical experience for accomplishing the great cause of national reunification. Emancipating the mind and seeking truth from facts are the core qualities of Deng Xiaoping Theory, which has been throughout the transformation of "One country, Two systems" from a scientific concept into reality in Hong Kong.

\section{The Enrichment and Development of the Central Government's Strategy of Governing Hong Kong}

The National People's Congress officially established "One country, Two systems" as a basic national policy of China in 1985. Since then, the basic policy of the central government governing Hong Kong has been supported by jurisprudence, which gradually moves towards standardization, institutionalization and legalization. The CPC Central Committee with Comrade Jiang Zemin as the core and the CPC Central Committee with Comrade Hu Jintao as the general secretary inherit the essence of Mao Zedong Thought and Deng Xiaoping Theory, firmly push forward the cause of "One country, Two systems" based on the ever-changing background of the times, further enrich and develop the central government's strategy of governing Hong Kong, and provide theoretical guidance and action guidelines for the country's prosperity and Hong Kong's development.

\subsection{Jiang Zemin: Ensure the Smooth Transition of Hong Kong, Maintain Its Stability and Prosperity, and Strengthen Its} Confidence in the Future

International society changed dramatically in the late 1980s and early 1990s, Eastern Europe changed drastically, the Soviet Union collapsed, and the domestic political turmoil still lingered. Against this background, the British government frequently pressed Beijing by playing false public opinion cards, with the intention of extending its colonial interests through the internationalization of the Hong Kong issue. Hong Kong is a piece of fat once obtained by Britain. Will they spit it out? Unwilling (Jiang, 2006). Facing all kinds of troubles and obstacles created by the British authorities, the CPC Central Committee with Comrade Jiang Zemin as the core assessed the situation and calmly responded to the central issue of "How to ensure the smooth transition of Hong Kong and how to maintain its stability and prosperity", thus strengthening the confidence of all circles at home and abroad in the future of Hong Kong.

First of all, it is in line with the will of the Chinese and British peoples to realize the smooth handover of Hong Kong and maintain stability and stability. The two sides should proceed from the fundamental interests of Hong Kong, focus on the overall situation and cooperate sincerely. However, the British side acted unilaterally. On the eve of Hong Kong's return to China, it quickly pushed forward the proposal of representative government and made great efforts in infrastructure projects. This political act of "You treat, I pay" went against the historical trend and was unpopular. Maintaining Hong Kong's stability and prosperity is the common interest of both China and Britain. To enhance the confidence of Hong 
Kong people, the British side should also do something (Jiang, 2006). Secondly, socialist China is rooted in the soil of Chinese civilization for more than 5,000 years, which can't be chaotic or pushed down. The Chinese nation has its own fine tradition, attaches importance to national integrity and will never succumb to any external pressure (Jiang, 2006). Britain's delusion that China will compromise or concede in the face of national justice is obviously overreaching. Thirdly, the people's army under the absolute command of our party has stood the test of revolution, and is like the Great Wall of Steel, always escorting the great cause of national sovereignty, territorial integrity and peaceful reunification of the motherland. Finally, we have full confidence in the future of Hong Kong. This self-confidence is based on "four affirmations", that is, "One country, Two systems" should be affirmed, the Sino-British Joint Declaration should be affirmed, the Basic Law of the Hong Kong Special Administrative Region should be affirmed, and "Hong Kong people ruling Hong Kong" and a high degree of autonomy should be affirmed (Jiang, 2006). On the one hand, we are highly vigilant against the British Hong Kong authorities taking the opportunity to create troubles and set up obstacles on the Hong Kong issue. On the other hand, Hong Kong's stability and prosperity are closely linked with the mainland, and we take favorable measures to implement everything that is conducive to realizing the core interests of Hong Kong people.

Jiang Zemin pointed out that "the Hong Kong issue occupies a large position in my mind. I am determined to solve this problem! If the Hong Kong problem is not solved well, it will be sorry for future generations" (Jiang, 2006). Practice has proved that Hong Kong has smoothly returned to the motherland and successfully responded to the impact of the Asian financial turmoil with the superb political wisdom of the CPC Central Committee and the strong backing of the mainland, initially demonstrating the strong vitality of "One country, Two systems".

\subsection{Hu Jintao: Deepen the Understanding of "One country, Two systems", Strengthen the Confidence of Patriots in Governing Hong Kong, Promote Hong Kong's Economic Development and Social Harmony}

Economic globalization is in the ascendant at the beginning of the new century. As the freest economy in the world, Hong Kong plays a unique role in national economic development and opening up. With the deepening of exchanges and cooperation between the Mainland and Hong Kong, the pattern of complementary advantages and common development between the Mainland and Hong Kong has gradually taken shape. Managing and coordinating two different social systems within a sovereign state to ensure their respective functions have put forward higher requirements for the Party Central Committee's ability to govern the country. The CPC Central Committee with Comrade Hu Jintao as General Secretary deepened the general plan of governing Hong Kong and further enriched the theory and practice of "One country, Two systems" in Hong Kong.

First, deepen the understanding of "One country, Two systems". Hu Jintao pointed out that "One country, Two systems" is a complete concept. "One country" is the premise of "two systems". Without "one country", there would be no "two systems". "One country" and "two systems" cannot be separated from each other, let alone opposed to each other(Hu, 2016). Only a comprehensive and accurate understanding of "One country, Two systems" can stimulate its superiority in the process of implementing this basic strategy and bring long-term prosperity and stability to Hong Kong citizens. From unswervingly implementing "One country, Two systems" to comprehensively and accurately understanding and implementing this policy, it shows that the central government has deepened its understanding of the law of "One country, Two systems". Secondly, strengthen the confidence of Hong Kong people governing Hong Kong and enhance the national identity. Hu Jintao pointed out that Hong Kong compatriots not only have the wisdom, ability and ways to manage and build the Special Administrative Region well, but also can play an active role in state affairs and share the dignity and glory of being Chinese with the people of all ethnic groups in China (Hu, 2016). To govern Hong Kong by Hong Kong people, we should not only stick to the basic norms of patriots governing Hong Kong, but also unite and lead the patriotic and Hong Kong-loving front, gather the forces of all social strata in Hong Kong, and prevent Western forces from interfering in Hong Kong affairs. Thirdly, focus on promoting Hong Kong's economic development. Economic function is the traditional advantage of Hong Kong society. How to consolidate the original advantages of international exchanges and institutional arbitrage and create new development advantages with the help of the mainland is the core issue of the central government's strategy of governing Hong Kong. The central government attaches great importance to Hong Kong's strategic position in national development, promotes exchanges and cooperation between the two places in trade relations, currency swap agreements, personal tourism and other fields through a close cooperation framework, and strives to enhance Hong Kong's domestic vitality and international competitiveness. Finally, maintain the prosperity, stability and harmony of Hong Kong society. The well-being of Hong Kong people must be based on social harmony and stability, and the central government is fully aware of it. During Hong Kong's fight against SARS and the international financial crisis, the central government steadfastly "stood up to Hong Kong" and adopted a series of "benefiting Hong Kong" policies to stabilize Hong Kong people's hearts and enhance Hong Kong's ability to deal with social risks. From prosperity and stability to the integration of harmonious ideas, this rich extension of social value goal orientation is the inner sublimation result of the central government's idea of governing Hong Kong. 


\section{The Central Government's Strategy of Governing Hong Kong Has Entered a New Era}

Since the 18th National Congress of the Communist Party of China, the development of "One country, Two systems" has entered a new era, which is also a new stage in the development of socialism with Chinese characteristics. The central government has played a more prominent role in promoting the governance of Hong Kong and Macao in depth in the new historical position. The status of "one country" has been further consolidated, and the interaction between "two systems" has been further optimized. However, with the practice of "One country, Two systems" stepping into deep waters, some deep-seated contradictions in Hong Kong society have become increasingly prominent. In the face of new opportunities and challenges, the CPC Central Committee with Comrade Xi Jinping as its core has stayed true to its founding mission, strengthened its confidence and determination in implementing "One country, Two systems" and forged ahead.

\subsection{The New Judgment on "One country, Two systems": Rich in Connotation, Broad and Profound}

Since the 18th National Congress of the Communist Party of China, General Secretary Xi Jinping has attached great importance to the issue of "One country, Two systems", put forward a series of new ideas, new theories and new requirements on the governance of Hong Kong and Macao, profoundly discussed the important position of Hong Kong and Macao in the national development strategy, and scientifically answered major theoretical and practical questions on the central government's governance of Hong Kong and Macao, which has become an important part of Xi Jinping Thought on Socialism with Chinese Characteristics for a New Era. General Secretary Xi Jinping's important exposition on the practice of "One country, Two systems" is not only based on the Marxist state theory, but also inherits the cultural essence of the collective leadership of the Communist Party of China on national peaceful reunification and regional governance, and at the same time is based on the realistic foundation of the great practice of socialism with Chinese characteristics. Among them, the new judgment on the governance of Hong Kong and Macao in the new era is rich in connotation, extensive and profound, runs through the historical context of national unity, national governance and national rejuvenation, and covers the essentials of governing Hong Kong scientifically, legally, comprehensively, by United front and by Hong Kong people. It is a systematic, complete and scientific theoretical chapter. For example, safeguarding the core interests of the country is combined with maintaining Hong Kong's prosperity and stability; Focusing on the landing of governance power and the return of people's hearts; The governance mode pays attention to the integration of national macro planning and Hong Kong local thinking; Carrying the national strategic layout of complementary advantages and common development between the mainland and Hong Kong (Xi, 2017). These important viewpoints and expositions have laid the theoretical foundation of the central government's strategy of governing Hong Kong in the new era, and are the innovation and development of "One country, Two systems" by General Secretary Xi Jinping.

\subsection{The New Orientation of "One country, Two systems": Sharing the Dream of National Rejuvenation}

From the 18th National Congress of the Communist Party of China, it is pointed out that "safeguarding national sovereignty, security, development interests and maintaining long-term prosperity and stability of Hong Kong and Macao" is the "fundamental purpose" of the practice of "One country, Two systems" and the central government's policies towards Hong Kong and Macao, and then the 19th National Congress of the Communist Party of China will adhere to "One country, Two systems" as a basic strategy for upholding and developing socialism with Chinese characteristics in the new era. This progressive approach to Hong Kong and Macao governance is scientific, practical and forward-looking. It reflects the central government's rich experience in the work of Hong Kong and Macao and confirms that the cause of "One country, Two systems" assumes a new position in the overall work of the Party and the country. Namely, the direction and position of the practice of "One country, Two systems" in Hong Kong and Macao for national development (promoting modernization of national governance system and governance capacity) and national rejuvenation (realizing the Chinese dream of the great rejuvenation of the Chinese nation). It can be seen that since the return of Hong Kong and Macao for more than 20 years, "One country, Two systems" has changed from the mode of national unification to the mode of national governance. "One country, Two systems" is being upgraded to a model of national rejuvenation in a new historical position. As General Secretary Xi Jinping said, continuously promoting the successful practice of "One country, Two systems" in Hong Kong is an important part of the Chinese dream; There is nothing impossible for the group, and what the people do is invincible (Xi, 2017).

\subsection{Hong Kong's Unique Advantages Are Irreplaceable: Institutional Arbitrage and International Exchanges}

General Secretary Xi Jinping pointed out that in the process of national reform and opening up in the new era, Hong Kong and Macao still have special status and unique advantages, and can still play an irreplaceable role (Xi, 2018). For Hong Kong, "One country, Two systems" is the biggest advantage, and the implementation of national strategies such as "the Belt and Road" initiative and "Guangdong-Hong Kong-Macao Greater Bay Area" construction is a new major opportunity. Because of its status as a free port and an international financial center, Hong Kong can exert a strong influence on the Chinese mainland through arbitrage trading, capital flow and mechanism transmission, which is an important bridge for 
European and American capital to enter the Chinese mainland market. Hong Kong's unique role in economic, trade and financial activities, international first-class software infrastructure and global communication network cannot be replaced by mainland cities in the short term. The central government's strategy of governing Hong Kong and Macao shows the practical consciousness of breaking the "hero of GDP alone". In the new stage of "One country, Two systems" development, Hong Kong must fully understand and accurately grasp its position and role in the national development strategy, consolidate its traditional advantages, and cultivate new advantages in order to better help the country to fully open up, integrate into the overall situation of national development, participate in the practice of national governance, and promote international cultural exchanges.

\subsection{A New Attempt of "One country, Two systems": Building Guangdong-Hong Kong-Macao Greater Bay Area Together}

General Secretary Xi Jinping pointed out that the main body of the state adopts the socialist system and some regions adopt the capitalist system in accordance with the law within a unified country, which has never been seen in human political practice before. This is a great innovation in terms of theory, system and governance (Xi, 2017). "One country, Two systems" does not rely on the central policy lever to deploy and replace resources that tend to be homogeneous in different regions within the same national system, but rely on endogenous innovation to optimize two systems of different natures within "One country". As a result of integration, they interact and influence each other, and it is very likely that an "institutional chemical reaction" will occur, resulting in better institutional resources. Among them, the role of "One country" is an essential "catalyst". Since the 18th National Congress of the Communist Party of China, the Central Committee has judged the situation and looked ahead, and promoted the Guangdong-Hong Kong-Macao Greater Bay Area construction from a regional cooperation framework to a national development strategy. With the development of "One country, Two systems", Hong Kong should coordinate with the national development strategic goal in the process of Guangdong-Hong Kong-Macao Greater Bay Area construction, not only do a good job in the hardware construction of system innovation, factor flow and platform cooperation at the economic and social level, but also do a good job in the top-level design and implementation scheme of software level such as cultural integration and national identity.

\subsection{New Thinking of "One country, Two systems": Keep a Low Profile and Move Forward}

General Secretary Xi Jinping pointed out that no matter what difficulties and challenges we encounter, our confidence and determination in the principle of "One country, Two systems" will never waver, and our confidence and determination in promoting the practice of "One country, Two systems" will never waver (Xi, 2016). Over the past 20 years, Hong Kong has made great achievements in the practice of "One country, Two systems", but it also faces various challenges. Practical problems, such as the simplification of economic structure, the confrontation of political parties against internal friction, the disparity between the rich and the poor, and the frequent youth social movements, have plagued the central government from time to time. If looking at Hong Kong as a separate capitalist economy without the background of "One country, Two systems", we can find that many problems facing Hong Kong society are exactly the same as those faced by western developed capitalist society. According to the viewpoint of Marxist political economy, the basic contradiction of capitalism, that is, the conflict between socialization of production and private possession of means of production, determines that it is bound to face structural and periodic crisis. So, can Hong Kong successfully resolve the universal contradiction of capitalist system? Obviously, the central government's strategy of governing Hong Kong in the new era gives a positive answer, but it needs to meet three basic conditions: First, comprehensively and accurately understand and implement "One country, Two systems", in which Hong Kong must be placed as a local administrative unit in China's holistic vision to think about the path to solve problems, rather than an independent political entity; Second, the complexity of the Hong Kong issue cannot be underestimated. The practice of "One country, Two systems" in Hong Kong is a long-term, arduous and tortuous process; The third is to allow the practice of "One country, Two systems" in Hong Kong to accumulate experience and lessons through "trial and error". After all, the practice of "One country, Two systems" is an unprecedented political undertaking, and its later achievements may bring great gospel to the institutional dilemma of global governance and the strategic choice of China's peaceful rise.

\section{Conclusions}

Winds and rains for more than 70 years. "One country, Two systems" has been transformed from theoretical conception to practical practice and from national unification mode to national governance mode under the scientific guidance of the central government's strategy of governing Hong Kong. Thanks to the concerted efforts of Hong Kong residents and mainland people, Hong Kong's economic and social development has made remarkable achievements. With an eye to the future, in the new journey of continuing to promote the practice of "One country, Two systems" in Hong Kong, it is necessary to constantly sum up the valuable experience of the central government in governing Hong Kong, and actively respond to new problems and challenges in the development of Hong Kong. 


\section{Acknowledgement}

This research was financially supported by China Postdoctoral Science Foundation (2019M663356) \& the Fundamental Research Funds for the Central Universities

(20wkpy85).

\section{References}

Deng, X. P. (1993). Selected Works of Deng Xiaoping. Beijing:People's Publishing House, 3, 59-60.

Edwin, W. M. (2016). Choices and differences: British and American reactions to the victory of the Communist Party in China. Beijing: Social Science Literature Publishing House, p.85.

Hu J. T. (2016). Selected Works of Hu Jintao. Beijing: People's Publishing House, 2-3, 592- 649.

Jiang, Z. M. (2016). Selected Works of Jiang Zemin. Beijing: People's Publishing House, 1, 82-118\&383-385.

Liu, S. Y. (1998). A concise history of Hong Kong. Hong Kong: Sanlian Bookstore Co., Ltd., p.246.

Mao, Z. D. (2013). Mao Zedong Chronicle (1949-1976). Beijing: Central Literature Publishing House, 5, $249-250$.

Xi, J. P. (2016). General Secretary Xi Jinping's series of important speeches. Beijing: Learning Publishing House \& People's Publishing House, p.183.

Xi, J. P. (2017). Speech at the Welcome Dinner of the Hong Kong Special Administrative Region Government. People's Daily, 2017-7-1(02).

Xi, J. P. (2017). Xi Jinping: the governance of China. Beijing: foreign languages press, 2, 433-437.

Xi, J. P. (2017). Xi Jinping's speech at the 20th anniversary of Hong Kong's return to the motherland and the inauguration ceremony of the fifth government of the Hong Kong Special Administrative Region. People's Daily, 2017-7-2(02).

Xi, J. P. (2018). Speech when meeting with the delegation from all walks of life in Hong Kong and Macao to celebrate the 40th anniversary of national reform and opening up. People's Daily, 2018-11-13(02).

Ye, J. Y. (1981). Chairman Ye Jianying further clarified the principles and policies of Taiwan's return to the motherland to realize peaceful reunification: it is suggested to hold equal talks between the two parties to implement the third cooperation. People's Daily, 1981-10-1(01).

Zhou, E. L. (1984). Selected Works of Zhou Enlai's United Front. Beijing: People's Publishing House, p.353.

\section{Copyrights}

Copyright for this article is retained by the author(s), with first publication rights granted to the journal.

This is an open-access article distributed under the terms and conditions of the Creative Commons Attribution license which permits unrestricted use, distribution, and reproduction in any medium, provided the original work is properly cited. 